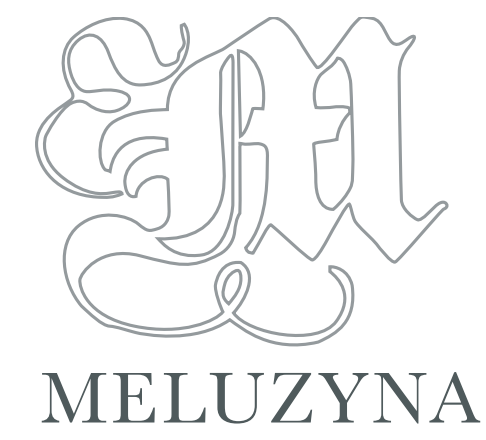

ISSN 2449-7339

1 (2014)

INEDITA

Katarzyna Chruściel*

Uniwersytet Śląski

\title{
Mowy weselne z pamiętnika Michała Obuchowicza - edycja krytyczna
}

W XVII-wiecznej Polsce mowy uznawano za nieodzowną część kultury wolnych narodów, a wymowa była podstawową umiejętnością każdego pełnoprawnego obywatela, nauczaną na wszystkich etapach edukacji szlacheckiej. Oratorstwo towarzyszyło mu potem w życiu publicznym i prywatnym¹.

Ślub szlachecki był w dawnej Polsce znaczącym wydarzeniem społecznym, a wspomnienia poszczególnych uroczystości pojawiają się częstokroć w dawnych pamiętnikach i sylwach. Do ważnych elementów celebracji zaślubin należało bez wątpienia wygłaszanie mów przez przyjaciół i rodzinę państwa młodych. Zapisywanie ważniejszych oracji było szeroko praktykowane wśród szlachty, a przykłady takich tekstów możemy odnaleźć w niejednej sylwie sarmackiej. Wśród wielu gatunków mów weselnych za szczególnie ważne należy uznać oracje wygłaszane przy oddawaniu panny, gdyż określały one moment, w którym kobieta zostawała oficjalnie powierzona opiece męża². Przykłady tychże mów można odnaleźć w kopii rękopisu Michała Obuchowicza. Niestety, choć pamiętniki Obuchowiczów ukazały się do tej pory w dwóch edycjach, żadna $\mathrm{z}$ nich nie uwzględniła zamieszczonych w nich oracji. Pierwsze wydanie relacji pamiętnikarskich przedstawicieli rodu Obuchowiczów, przygotowane przez Michała Balińskiego, po-

\footnotetext{
e-mail autora: kat.chrusciel@gmail.com

1 Zob. np.: M. Korolko, Wyniki i perspektywy badań nad barokową prozą oratorską, [w:] Wśród zagadnień polskiej literatury barokowej. Cz. I: Światopogląd - genologia - topika, red. Z.J. Nowak, Katowice 1980, s. 53-54.

2 M. Barłowska, Jerzy Ossoliński. Orator polskiego baroku, Katowice 2000, s. 197; M. Trębska, Staropolskie szlacheckie oracje weselne. Genologia, obrzęd, źródła, Warszawa 2008, s. 145-150, zob. także: K. Mroczek, Epitalamium staropolskie. Między tradycja literacka a obrzędem weselnym, Wrocław 1989.
} 
wstało w Wilnie w 1859 roku i nosiło tytuł Pamiętniki historyczne do wyjaśnienia spraw publicznych $w$ Polsce XVII wieku posługujące, w dziennikach domowych Obuchowiczów i Cedrowskiego pozostałe. Edycja obejmowała lata 1630-1654 z życia Kazimierza Obuchowicza, a ponadto w tomie tym zamieszczono pamiętniki dwóch innych przedstawicieli rodziny: Michała Leona oraz Teodora Hieronima ${ }^{3}$. Przy tworzeniu tego wydania Baliński opierał się na kopii pamiętnika, sporządzonej przez Adolfa Kobylińskiego. Wiadomo o nim tyle, że był to sąsiad rodziny Obuchowiczów i przygotował odpis na specjalne życzenie Aleksandra Obuchowicza, choć najprawdopodobniej kopista ten nie posiadał specjalistycznej wiedzy w dziedzinie filologii ${ }^{4}$.

Niedoskonałości powyższej edycji doprowadziły do drugiego wydania pamiętników w 2003 roku w Warszawie. Nad nowym opracowaniem, pt. Pamiętniki Filipa, Michała i Teodora Obuchowiczów (1630-1707) czuwali historycy: Henryk Lulewicz oraz Andrzej Rachuba. Ta edycja, w odróżnieniu od poprzedniej, jest naukowym wydaniem krytycznym. Z braku możliwości dotarcia do autografu badacze zadecydowali, że jej podstawą będą rękopisy z Biblioteki Polskiej Akademii Nauk w Kórniku. Wykorzystano manuskrypt o sygnaturze 1303 zatytułowany Zbiór akt, korespondencji i wypisów z 16-19 w., który zawiera pamiętniki Filipa Kazimierza i Teodora Hieronima Obuchowiczów, oraz rękopis nr 358. W tym ostatnim można znaleźć skopiowane w końcu XVIII w. zapiski Michała Leona Obuchowicza. Ponadto edytorzy postanowili w miarę możliwości nie korzystać przy pracy z wersji Balińskiego i bazować wyłącznie na zgromadzonych przekazach rękopiśmiennych ${ }^{5}$. W drugiej edycji znalazły się wspomnienia Kazimierza, Michała i Teodora Obuchowiczów oraz aneksy. Źródła pojawiające się w dodatkach zawierają także teksty nieobecne w podstawie edycji, zaczerpnięte $\mathrm{z}$ innych rękopisów.

Współcześni edytorzy różnie rozwiązują problem mów zamieszczanych w zabytkach pamiętnikarskich ${ }^{6}$. Nie ma pod tym względem ustalonej normy, toteż osoby dokonujące opracowania dzieł staropolskich same decydują, w jaki sposób wykorzystać w tekście zasadniczym istniejące dodatki, aby wynik końcowy jak najlepiej realizował cele publikacji. Wydanie pamiętników Obuchowiczów pod redakcją Andrzeja Rachuby nie uwzględnia kilku mów, które znajdują się w rękopisie 358 z Biblioteki PAN w Kórniku:

3 Pamiętniki Filipa, Michała i Teodora Obuchowiczów (1630-1707), pod red. A. Rachuby, oprac. H. Lulewicz i A. Rachuba, Warszawa 2003, s. 9.

4 Ibidem, s. 15-16.

5 Ibidem, s. 13.

6 Andrzej Rachuba we wstępie do Pamiętnika Jana Władysława Poczobuta Odlanickiego zaznacza, że choć w oryginalnym tekście pamiętnika pojawiają się różnego rodzaju zapiski, takie jak mowy lub wiersze, zdecydował się jednak zamieścić jedynie te, które mają bezpośredni związek z osobą Odlanickiego oraz jego potomkami (J.W.P. Odlanicki, Pamiętnik (1640-1684), oprac. A. Rachuba, Warszawa 1987, s. 92-93). Bohdan Królikowski, który dokonał opracowania Diariusza Marcina Matuszewicza, zdecydował się zamieścić w swoim wydaniu wszystkie dodatkowe zapiski umieszczone w dzienniku przez autora. Zaznaczył, że choć ich pojawienie się może nieco rozbijać ciągłość relacji, to, jego zdaniem, obecność tychże elementów znajduje swoje uzasadnienie. Królikowski wspomina również o poprzedniej edycji dzieła, autorstwa Adolfa Pawińskiego, z 1876 roku. Nadmienił, że wersja wcześniejsza pozbawiona jest wielu tekstów, które ówczesny wydawca uznał za niepotrzebne lub niewłaściwe dla druku. Co więcej, Pawiński często nie informował czytelnika o tych pominięciach (M. Matuszewicz, Diariusz życia mego 1714-1757, oprac. i wstęp B. Królikowski, kom. Z. Zielińska, t. 1, Warszawa 1986, s. 862). 
1. Mowa za dyrekcyji mojej koła wojskowego do J[ego]m[oś]ci Pana Krzysztofa Zawiszy, marszałka wielkiego W[ielkiego] Ks[ięstwa] L[itewskiego], komisarza natenczas od J[eg]o $\mathrm{K}$ [rólewskiej] M[oś]ci przy dokończeniu sesyji, który ad combinationem anim[orum] et $\operatorname{arm}[\text { orum }]^{7} \mathrm{z}$ lewym skrzydłem prawego był wyprawiony po ujęciu wojska w związku, w Michnowiczach dnia 24 decembra 1663 (k. 32v-33).

2. Mowa do Króla J[ego]m[oś]ci w senacie, gdym był posłem spod Mohilowa in anno 1665 z J[ego]m[oś]ci Panem Konstantym Pacem, chorążym nadwornym W[ielkiego] Ks[ięstwa] L[itewskiego], kollegą natenczas moim i innemi przy oddawaniu chorągwi moskiewskich więcej stu z wiktoryji pod Witebskiem, która była nad Chowańskim in anno ${ }^{8} 664$, latem, za dziełem J[ego]m[oś]ci Pana Michała Paca, wojewody smoleńskiego, hetmana polnego W[ielkiego] Ks[ięstwa] L[itewskiego] (k. 34).

3. Mowa do Króla J[ego]m[oś]ci Michała, będąc posłem z sejmiku nowogrodzkiego in anno 1673 (k. 34v-35).

4. Mowa na pogrzebie Księżny Jejm[oś]ci Radziwiłłowej, podkanclerzynej W[ielkiego] Ks[ięstwa] L[itewskiego], siostry rodzonej Króla J[ego]m[oś]ci Jana III, czyniąc kondolencyją od Królestwa Ichm[ościów] Książęciu J[ego]m[oś]ci Karolowi Radziwiłłowi, podkanclerzemu W[ielkiego] Ks[ięstwa] L[itewskiego], synowi w Nieświżu (k. 35).

5. Mowa przy ślubie oddając Jejm[ość] Pannę Pudencyją Gosiewską w stan ś[więty] małżeński J[ego]m[oś]ci Panu Iwanowskiemu, rotmistrzowi przez mię od J[ego]m[oś]ci Pana Korwina Gosiewskiego, podskarbiego wielkiego W[ielkiego] Ks[ięstwa] L[itewskiego], hetmana polnego w Wilnie na komisyji z związkowymi anno 1662, mensis Septembris (k. 35v-36).

6. Mowa druga przy oddaniu p[anny] młodej (k. 36v-37).

Mowy, które pojawiają się w rękopiśmiennej kopii pamiętnika Michała Leona Obuchowicza, zostały tam umieszczone bez podania autorstwa. Stwarza to pewne problemy w jednoznacznym określeniu, który z przedstawicieli rodziny Obuchowiczów był ich autorem.

Filip Kazimierz Obuchowicz dość często występował w roli mówcy na weselach szlacheckich. W jego pamiętniku pojawia się wzmianka, że oddawał prezenty, m.in. na ślubie królewny Anny Katarzyny Konstancji z księciem neuburskim Filipem Wilhelmem9 . Choć o tym nie wspomina, to można sądzić, że wygłosił z tej okazji stosowną mowę. Tego typu oracje nie były jednak uznawane za szczególnie istotne, więc rzadziej je zapisywano. Niemożliwe, by występował w roli oratora również na weselu Pudencji Gosiewskiej i rotmistrza Iwanowskiego. Rękopis podaje, że wesele to odbyło się we wrześniu 1662 roku, a Filip Kazimierz zmarł w roku 1656. Bardziej prawdopodobne, że autorem oracji weselnych był jeden z jego synów - Michał lub Teodor. Choć żaden z nich nie wspomina o uczestnictwie w takiej uroczystości, to zapewne chodzi tu o Michała

\footnotetext{
7 ad combinationem animorum et armorum - aby połączyć ludzi i oręż (albo: aby połączyć siły)

8 in anno - roku; połączenie in anno to polonizm - w łacinie klasycznej nie powinno być w tym miejscu przyimka

9 Pamiętniki Filipa, Michała i Teodora Obuchowiczów..., s. 218.
} 
Obuchowicza. W jego pamiętniku nazwisko Gosiewskich pojawia się stosunkowo często ${ }^{10}$. Wiadomo również, że pamiętnikarz poznał hetmana Gosiewskiego i zacieśnił z nim więzy w trakcie niewoli moskiewskiej w 1660 roku. Można więc sądzić, że stosunki Michała z Gosiewskimi doprowadziły do napisania mowy przy oddaniu panny Pudencji Gosiewskiej, on również zapisał w postaci wzoru następującą po niej „Mowę drugą przy oddawaniu p[anny] młodej”.

Michał Leon Obuchowicz w 1660 roku piastował funkcję dowódcy pułku. Jego zadaniem było zdobycie informacji o sile i ruchach wojska Iwana Andrejewicza Chowańskiego. Niestety, w czasie marszu oddział Obuchowicza został pokonany przez Piotra Chowańskiego, a sam Obuchowicz dostał się do rosyjskiej niewoli. Jego ranga uchroniła go przed wysłaniem w głąb obcego kraju. W niewoli właśnie poznał Wincentego Gosiewskiego. Ta znajomość w dużym stopniu przyczyniła się do oswobodzenia Obuchowicza, ponieważ hetman nalegał, by uwolniono go wraz z pozostałymi oficerami. Ze względu na tę znajomość pamiętnikarz mógł być później obecny na zaślubinach panny Pudencji Gosiewskiej"

Oracje stanowią istotną część zapisków pamiętnikarskich i nie powinno się ich wykluczać z edycji. Co prawda jest to osiemnastowieczna kopia, w której nieznany zapisywacz zestawił kilka tekstów związanych z rodziną Obuchowiczów (zob. opis źródła), jednak jego decyzja powinna i dziś zobowiązywać do zachowania integralności źródła. Jak można zauważyć, towarzyszące relacjom mowy niejednokrotnie uzupełniają informacje znajdujące się w pamiętnikach, albo też poszerzają kontekst spraw już rozpoznanych. Mowy należą też do cennych źródeł, na podstawie których możemy poszerzyć wiedzę o kulturze i języku epoki.

\footnotetext{
10 Michał Obuchowicz wspomina kilkakrotnie w swoim pamiętniku o hetmanie polnym Wincentym Gosiewskim herbu Ślepowron. Z żalem wspomina o zamordowaniu hetmana (w listopadzie 1662 roku). Od odnotowania tego wydarzenia rozpoczyna Obuchowicz swój Diariusz wyprawy przeciwko Moskwie.

11 Ibidem, s. 134-138.
} 


\section{Mowa przy ślubie, oddając Je[j]m[ość] Pannę Pudencyją Gosiewską ${ }^{1}$ w stan ś[więty] małżeński J[ego]m[oś]ci Panu Iwanowskiemu², rotmistrzowi przez mię, od J[ego]m[oś]ci Pana Korwina Gosiewskiego ${ }^{3}$, podskarbiego wielkiego W[ielkiego] Ks[ięstwa] L[itewskiego], hetmana polnego w Wilnie, na komisyji z związkowymi a[nno] $1662^{4}$, mensis Septembris}

[1] Tak nas porządna wszechmocnej Opatrzności Boskiej chciała mieć dyspozycyja, iż co przedwieczną swoją ugruntowała decyzyją, to wiekorodną zatrzymać deklarowała konserwacyją. [2] Wszystkie rerum mutationes lubo ab ortu prędko pospieszają ad occasum, jednak samychże siebie albo renowacyją, albo nową tym podobnemi erekcyją rozciągłe tak przewybornej machiny napełniają granice. [3] I sam człowiek, najprzedniejsza architektury Boskiej zabawa, ten łaskawy najwyższej dobroczynności otrzymał przywilej, że jakoby wieczną samego siebie zachowywał przytomność, kiedy successiva posteritate imienia swego widzi nieustającą kalkulacyją. [4] Owo zgoła cokolwiek jest in natura, ad eam unitatem i przyrodzonej konserwacyji wrodzonym postępuje pochopem, aby nierozdzielna naturalis vinculi zostawała catena.

[5] Przyznawać to, Mości Panie rotmistrzu Jego K[rólewskiej] Mości, musisz, żeś dotąd traktując ojczyzny usługę, barziej na dywizyją przeciwną naturze zarabiał, kiedyś tak wielekroć ochotą i wolą własną wzbudzony, odważnie zdrowie swe in aleam belli puszczał. [6] Ale jako nie zawsze surowy Mars między hucznemi trąb okrzykami bohatyrską się popisuje ręką, czasem z łaskawemi miewa koniunkcyją boginiami ${ }^{5}$, tak i alumnos se $<q u>$ aces sui do podobnych prowadzi gustów, aby dożywotnią przyjaźnią ${ }^{6}$ przeszłych trudów swoich smakując memoriam, pożądanego zamysłu otrzymali effectum. [7] Przyznawać i to W[asza] M[ość] Pan możesz, żeś ad eam serc unitatem z Jejmość Panną Pudencyją Gosiewską nie innym przystąpiłeś torem, jedno wprzód Supremi Numinis dobrotliwą manudukcyją, potym pomnażaniem dobrodziejstw J[aśnie] W[ielmożnego] Jegomości P[ana] podskarbiego wielkiego i hetmana polnego Wielkiego Księstwa Litewskiego, tudzież samej Jejmości Pani podskarbinej mojej Miłościwej Pani, którzy

\footnotetext{
Tyt. mensis Septembris - we wrześniu

[1] dyspozycyja - rozporządzenie, postanowienie | ugruntowała decyzyja - utwierdziła decyzją | wiekorodna - trwającą wieki | konserwacyją - zachowaniem, utrzymaniem

[2] rerum mutationes - przemiany rzeczy | ab ortu - od początku | ad occasum - ku końcowi | renowacyją - odnową, odbudową | erekcyją - założeniem, powstaniem

[3] architektury Boskiej zabawa - budowania Boskiego dzieło | przytomność - obecność | successiva posteritate - w następnych pokoleniach | kalkulacyja-rachowanie

[4] in natura - w przyrodzeniu; w naturze, w charakterze człowieka | ad eam unitatem - do tej jedności | konserwacyji - zachowania | postępuje pochopem - postępuje z ochotą | aby nierozdzielna naturalis vinculi zostawała catena - aby trwał nierozerwany łańcuch naturalnej więzi (tj. aby kontynuowane było następstwo pokoleń)

[5] traktując ojczyzny usługę - praktykując służbę ojczyźnie, służbę rycerską | dywizyja - część | wzbudzony - pobudzony | in aleam belli - na hazard wojenny, tj. ryzyko wojenne

[6] alumnos se<qu>aces sui - wychowanków, którzy za nim stale podążają | memoriam - wspomnienia (dosł. pamięć) | effectum - rezultat

[7] ad eam [...] unitatem - do tej jedności | przystąpiłeś torem - przystąpiłeś drogą | jedno wprzód - tylko najpierw | Supremi Numinis - Najwyższej (Bożej) Woli | manudukcyja - wskazaniem/pouczeniem
} 
unitatem dobrych przymiotów W[aszej] M[ości] Pana do usługi ojczyzny stosujących, unitatem nieodmiennej powolności w zawziętym umyśle do pozyskania przyjaźni Jejmości Panny Gosiewskiej, unitatem zacnego klejnotu szlacheckiego w domostwie W[aszej] M[ości] Pana antiquitus ufundowanego uważywszy, tę krwie swojej unitatem, a bezpieczniej rzeknę - unionem, i drogą perłę do wiekuistej przyjaźni W[aszej] M[ości] Panu ofiarują. [8] Drogą zaiste w zacności prześwietnego domu Ichmościów Panów Korwinów Gosiewskich, których tym znaczniejsze światu okazały się decora, im same nieba hojnie na nich swych wylały faworów dowody. [9] I jeżeli kiedy volatus avium ${ }^{8}$ szczęśliwe godła rzeczompospolitym albo wysokich dzieł mężom pertendebant, $\mathrm{w}$ tej zaiste przezacnej familiji wiekopomne wyrazili auguria, kiedy na rycerskiej przyłbicy zacnego onego Korwina Rzymskiego9 ${ }^{9}$, tej starożytnej Ichmościów Panów Korwinów Gosiewskich posteritatis protoplasta, caelo demissus ales herbowny klejnot Ichmościów usiadszy, dotąd światu chwalebnych w boju i w pokoju ${ }^{10}$ mężów i życzliwych w radzie senatorów wystawuje. [10] Zasadził gniazdo szczęśliwy Ślepowron na wysokiego zacnością i odwagą Korwina szyszaku" ${ }^{11}$, jakoby potomności pewny podając hieroglifik, że żelazne filary upadającej ojczyźnie ${ }^{12} \mathrm{z}$ tego świetnego domu wychodzić miały. [11] Nie trzeba mi się w tym szyroko rozwodzić, bo jaśniejsze odważnych Hektorów ${ }^{13}$ dzieła nie tak się by największą fakundyją ozdabiają, jako swoją jaśnieją zacnością. [12] Dość na tym, że tak wielkich Korwinów oraz imienia i cnoty tuens, szczęśliwie w ojczyźnie naszej terrori hostibus, amori Patriae ta zacna perennat familija, ponieważ i pierścień rostro alitis trzymany, aeternitatis nigdy nieustającej sławy symbolizuje circulum, która jako dawniejszym, tak i naszym per tot haeroes tej sławnej prozapiji jaśnieje wiekom.

[13] Drogą perłę w tym pierścieniu zasadzoną bierzesz Waszm[oś]ć Pan, M[ości] P[anie] rotmistrzu, kiedy obrócisz oko na chwalebne w cnotach i wychowaniu uczciwym przez cnych rodziców ${ }^{14}$ Jejmości Panny Pudencyji Gosiewskiej manudukcyją postępki. [14] Teć to są dożywot-

[7] unitatem - jedność, tożsamość | nieodmiennej powolności - niezmiennej przychylności |w zawziętym umyśle w powziętym zamyśle | pozyskania przyjaźni - (w kontekście matrymonialnym) do pozyskania uczuć | unitatem jedność (tj. tożsamość) | klejnotu szlacheckiego - herbu szlacheckiego | antiquitus - w dawnych czasach | ufundowanego - nadanego | uważywszy - uznawszy | unitatem - jedność | unionem - gra słowna oparta na polisemii: unio oznacza zarówno 'połączenie', jak i 'perłę’ | drogą perłę - tj. pannę | do wiekuistej przyjaźni [...] ofiarują - oddają w stan małżeński

[8] decora - ozdoby | faworów dowody - dowody przychylności

[9] volatus avium - loty ptaków | pertendebant - zapewniły | wyrazili - odnosi się do wspomnianego w poprzednim zdaniu nieba | auguria - wróżby [z lotu ptaków] | posteritatis - potomności | caelo demissus ales - ptak, który zleciał z nieba, tj. tutaj kruk | wystawuje - prezentuje

[10] heroglifik - znak

[11] fakundyja - wymową

[12] tuens - strzegąc | terrori hostibus, amori Patriae - na postrach wrogom, ku miłości Ojczyzny | perennat - trwa | rostro alitis - $\mathrm{w}$ dziobie ptasim | aeternitatis - wieczności | circulum - krąg | per tot haeroes - dzięki tylu bohaterom | prozapiji - rodowi

${ }^{[13]}$ perłę [...] zasadzona - umieszczoną perłę 
niej przyjaźni największe gusty i korzyści, virtutem bonorum optimam przy znacznych fortuny aukcyjach odbierać, którą się nie tylko z zacnego urodzenia swego Jejmość Panna ozdabia, ale z przykładnych aktów i rodzicielskiej prawie dyrekcyji przezacnej damy J[aśnie] W[ielmożnej] Jejmości Pani podskarbinej Wielkiego Księstwa Litewskiego tym większą bierze estymacyją i cokolwiek w oblubienicy swej godnego W[asza] M[ość] Pan i do tej przyjaźni powabnego uważyłeś, to wszystko jako ze źródła cnót wysokich i chwalebnych matronalis pudicitiae przymiotów, na tę ukochaną W[aszej] M[ości] Pana sponsam wypłynęło.

[15] Bierzże tedy W[asza] M[ość] Pan z tak wielu ozdób uformowaną perłę, a w skrytej ją serca swojego złożywszy skarbnicy, tej zostawaj speranije, że to szczęśliwe złączenie ad maiora intencyj W[aszej] M[ości] Pana decus ac robur będzie, a jako dotąd szczodrym uznaniem łaski obojga Ichmościów dobrodziejów swoich tej fortunie szczęśliwą uczyniłeś coronidem, tak tychże uprzejme sobie odbieraj vota, abyś w pożądanym mutue caritatis pożyciu długowieczną sercem tych, które dziś obejmujesz z ręku Ichmościów szczęśliwości, w spólnym sukcesów powodzeniu z Jejmość Panną Gosiewską przepędzał, et tandem seri claudant tua lumina nati.

\section{Przypisy}

1 Pudencyja Gosiewska - nieznana krewna Wincentego Gosiewskiego. Hetman miał troje dzieci z Magdaleną Konopacką: Bogusława, Teresę oraz Zofię (A. Przyboś, Gosiewski »Gąsiewski« Wincenty Aleksander, [w:]: Polski słownik biograficzny, t. 8, red. K. Lepszy, Wrocław 1959, s. 346)

2 Pan Iwanowski - najprawdopodobniej mowa o Hieronimie Iwanowskim, który służył w dywizji Wincentego Gosiewskiego jako dowódca piechoty węgierskiej

3 Korwin Gosiewski - tj. Wincenty Korwin Gosiewski, herbu Ślepowron (1620-1662), syn wojewody smoleńskiego Aleksandra Gosiewskiego; podskarbi wielki litewski, hetman polny, starosta: oszmiański, wieliski, puński, markowski, łodziejski

4 w Wilnie na komisyji z związkowymi anno 1662 - odnosi się do komisji wileńskiej w 1662 roku, która została powołana do zapłaty wojsku; Wincenty Gosiewski pełnił w niej funkcję dyrektora, aż do 29 listopada, gdy został zamordowany (A. Filipczak-Kocur, Litewskie komisje wojskowo-skarbowe w XVII wieku, „Kwartalnik Historyczny” 2002, nr 3, s. 98-117)

5 z łaskawemi miewa koniunkcyją boginiami - według mitów rzymskich Mars miał liczne kochanki, najsłynniejszy był jego romans z boginią Wenus (zob. P. Grimal, Słownik mitologii greckiej i rzymskiej, tłum. zbiorowe, Wrocław 1997, s. 220)

6 dożywotnia przyjaźniq - tj. małżeństwem; mówienie o małżeństwie jako o dożywotniej przyjaźni było stałym określeniem w kulturze sarmackiej

7 Jejmości Pani podskarbinej - odniesienie do żony Wincentego Gosiewskiego, Magdaleny, którą była córka kasztelana elbląskiego Oktawiana Konopackiego

[14] virtutem bonorum optimam - najwyższy przymiot dobroci | fortuny - szczęścia, pomyślności | aukcyjach - pomnażaniach | aktów - działań, czynów | dyrekcyji-dozoru, kierownictwa | estymacyja - szacunek, poważanie | uważyłeś - zauważyłeś | aktów - działań, czynów | dyrekcyji-dozoru, kierownictwa | estymacyja - szacunek, poważanie | uważyłeś - zauważyłeś | virtutem bonorum optimam - najwyższy przymiot dobroci | fortuny - szczęścia, pomyślności | aukcyjach-pomnażaniach | aktów-działań, czynów | dyrekcyji-dozoru, kierownictwa | estymacyja - szacunek, poważanie | uważyłeś - zauważyłeś | matronalis pudicitiae - matczynej obyczajności | sponsam - oblubienicę

${ }^{[15]}$ zostawaj speranije - miej nadzieję (z łac. sperare - mieć nadzieję) | ad maiora intencyj - co do większych intencji | decus ac robur - ozdoba i moc | uznaniem łaski - doznaniem łaski | coronidem - ukoronowanie, zakończenie | vota - życzenia | mutue caritatis - wzajemnej miłości | et tandem seri claudant tua lumina nati - a na koniec niechaj ci wnuki zamkną oczy 
8 volatus avium - wróżby z lotów ptaków miały w starożytnym Rzymie wielkie znaczenie, a do ich wyników podchodzono bardzo poważnie; w niektórych przypadkach niedopełnienie takiej przepowiedni było uznawane za poważne wykroczenie religijne (zob. M. Jaczynowska, Religie świata rzymskiego, Warszawa 1987, s. 45-46)

9 Korwina Rzymskiego - tj. Valerius Corvinus, tribunus militum, legendarny przodek rodu Gosiewskich

10 chwalebnych $w$ boju i pokoju - topos laudacyjny arma et toga (oręż i toga), symbol działań politycznych

11 Zasadził gniazdo szczęśliwy Ślepowron na [...] Korwina szyszaku - nawiązanie do legendy herbowej, według której podczas bitwy z Galami na szyszaku Korwina rzymskiego usiadł kruk, który swoimi skrzydłami i dziobem atakował wroga, co uniemożliwiło mu właściwe widzenie. Doprowadziło to ostatecznie do zwycięstwa domniemanego przodka rodu Gosiewskich (K. Niesiecki, Herbarz polski, wyd. i uzup. J.N. Bobrowicz, t. 8, Lipsk 1841, s. 395-396; por. też Titus Livius, $A b$ urbe condita, 1. 7. c. 26, 32)

12 żelazne filary [...] upadającej ojczyźnie - topos laudacyjny, wyobrażenie wybitnych obywateli jako podpór/słupów państwa przedstawianego jako gmach

13 Hektor - bohater trojański, syn króla Priama, bohater Iliady Homera

14 cnych rodziców - nie wiemy nic o rodzicach Pudencji Gosiewskiej 


\section{Mowa druga przy oddaniu p[anny] młodej}

[1] Niech zamilknie i swojej się niepewnej zawstydzi opiniji ten, co powiedział, że damy kawalerom są to malum necessarium ${ }^{1}$. [2] A cóż barziej in cursu życia tego ukontentować, co większe gusty i plezyry przynosić może, jeżeli nie koniunkcyja z miłym i szczerowiernym przyjacielem, którego komu łaskawa Prowidencyja Boska ordynuje, może się pochlubić, że skarb nalazł, ceną swoją wszytkie, by też najkosztowniejsze, przechodzący skarby. [3] I dlategoż przezorny machiny świata tego Architekt, gdy na ukontentowanie człowieka wszytkie mu kreatury do rządów i wolnej dyspozycyi podał, wszelkim szczęściem ukoronował, panem go zgoła i jedynowładcą universi postanowił, postrzegł przecie jeden i niemały defekt, a cóż takiego? [4] A to, że male solum hominem esse ${ }^{2}$. A tak, gdy mu ukochanego obmyślił przyjaciela, dopioro doskonałe dzieło, dopioro complementum łaski i szczodrobliwości swojej uczynił. [5] Ale cóż tu po szyrokich na aprobatę tego dokumentach, ponieważ i sam człowiek zwyczajnie abhorret solitudinem, który z natury swojej jest animal sociabile ${ }^{3}$.

[6] Doznałeś i sam W[asza] M[ość] Pan tego, Mości P[anie] N., jako jest przykra, jako tęskliwa i nieznośna solitudo, czemu chcąc mederi, szukałeś skarbu tego, którym się to dufny oznacza przyjaciel i nalazłeś Deo duce, comite Fortuna ${ }^{4}$, a w zacnym i starożytnym domu Ichmościów $\mathrm{P}$ [aństwa] N., którego to ozdoby i preminencyje gdybym chciał tu recensere i wywodzić, zdałbym się bardziej peregrinis loqui non civibus ${ }^{5}$. [7] Dość na tym, że ta zacna prozapija nie tylko domowemi od tak dawnego czasu antenatów swoich i teraz fulget honorami, ale też niemniej koniunkcyją z przedniemi w tej Rzeczypospolitej zdobi się familijami.

[8] Aleć nie tu jeszcze koniec faworów łaskawego nieba przeciwko Waszmości M[iłościwemu] Panu, że też zacnego domu swego decora łączysz z wysoką Ichmościów P[aństwa] N. familiją, to pro summo W[asza] M[ość] Pan musisz przyznać beneficio, kiedy ta dama dostaje się in sociam vitae et thori W[aszej] M[ości] Panu, która nie tylko z własnej swojej do wszelkich cnót inklinacyji, ale też nie mniej z przykładu dobrej i dozornej J[ejmości] Paniej N., matki i dobr[odziejki]

[1] malum necessarium - zło konieczne

[2] in cursu - w biegu, w czasie trwania | plezyry - rozrywki, przyjemności (z franc. plaisir) | koniunkcyja - połączenie | Prowidencyja Boska - Opatrzność | ordynuje - wyznacza | przechodzący - przewyższający

[3] Architekt - tj. Bóg | ukontentowanie-zadowolenie | kreatury-stworzenia | wolnej dyspozycyji-swobodnego dysponowania | universi - wszystkiego, całego świata

[4] male solum hominem esse - „Nie jest dobrze, żeby mężczyzna był sam” | complementum - dopełnienie

[5] szyrokich - wyszczególniających, rozwlekłych | aprobatę-przyjęcie, zaakceptowanie | dokumentach-dowodach | abhorret solitudinem - wzdraga się przed samotnością | animal sociabile - istotą społeczną

[6] solitudo - samotność | mederi - zapobiec | dufny-zaufany | Deo duce, comite Fortuna - mając Boga za przewodnika, Fortunę (czyli Los) za towarzyszkę | preminencyje - znakomitości | recensere - wyliczać szczegółowo | peregrinis loqui non civibus - do przybyszów z daleka (cudzoziemców) mówić, nie zaś do miejscowych (dosł. obywateli)

[7] prozapija - ród | fulget - jaśnieje, promienieje | koniunkcyja - połączeniem, tj. pokrewieństwem

[8] faworów [...] przeciwko - życzliwości [...] dla | decora - ozdoby | pro summo [...] beneficio - za najwyższe dobrodziejstwo | in sociam vitae et thori - jako towarzyszka życia i łoża | inklinacyji-skłonności | dozornej-pilnującej 
swej, edukacyji ślicznemi jest hojnie przyozdobiona przymiotami, w której się to niechybnie spełni, że uxor bona est viri corona ${ }^{6}$. [9] Już tedy krótko tę kończąc mowę moją, mogę przypomnieć słowa Extemporanei oratoris ${ }^{7}$ przy podobnym akcie wymówione: haec est Eleonora in illam Domine acipe, ama et honora ${ }^{8}$, a ja zaś mówię: ta jest etc. W[asza] M[ość] P[anie] Mości P[anna] N., z należytym honorem przyjmi onę do serca i do ręki, Bogu za tak łaskawą manudukcyją, matce i dobrodziejce za macierzyńskie łaski pełne wdzięczności oddawaj dzięki.

\section{Przypisy}

1 malum necessarium - zob. św. Augustyn, Contra Julianum haeresis Pelagianae defensorem (PL 44, 809) (1. 4, c. 8)

2 male solum hominem esse - cytat z Księgi Rodzaju: 2, 18 (Biblia Tysiąclecia: Pismo Święte Starego i Nowego Testamentu w przekładzie z języków oryginalnych, Poznań 2008, s. 4)

3 animal sociabile - nawiązanie do sformułowania Arystotelesa, że człowiek jest zoon politicon, ujętego w sentencji św. Tomasza z Akwinu: „homo naturaliter est animal sociale” (Summa theologiae. T. 56: De sacramentis, qu. 65, p. 1)

4 Deo duce, comite Fortuna - parafraza słów z Epistulae ad Familiares (1. 10. ep. 3, c. 2) Cycerona („virtute duce, comite fortuna")

5 peregrinis loqui non civibus - stała formuła pojawiająca się w pochwałach kierowanych do szlachty

6 uxor bona est viri corona - odwołanie do Księgi Przypowieści 12, 4: „Koroną męża jest dzielna żona, a próchnicą jego kości - bezwstydna”; Pismo Święte Starego i Nowego Testamentu..., s. 658

7 Extemporanei oratoris - M. Radau, Orator extemporaneus, sive Artis oratoriae breviarium bipartitum [...], Amstelodami, apud J. à Meurs, 1655

8 haec est Eleonora in illam Domine acipe ama et honora - cytat (słowa biskupa Eustachego Wołłowicza przytoczone przez M. Radaua, Orator extemporaneus..., s. 225) zniekształcony, powinno być: „Haec est Lenora, Tu illam in coniugem accipe, ama et honora” - „Oto jest Lenora, pojmij ją za małżonkę, kochaj i szanuj”

[8] uxor bona est viri corona - dobra małżonka koroną (ozdobą) jest męża

[9] manudukcyjq - przewodnictwem 


\section{Komentarz edytorski}

\section{Opis źródła}

Podstawą edycji jest osiemnastowieczna kopia, znajdująca się w rękopisie Biblioteki Polskiej Akademii Nauk w Kórniku: sygn. 358, in folio, k. 43. Tytuł biblioteczny: Manuskrypt do dzieiów za Krola Jana Kazimierza od 1660 do 1665 pa Obuchowicza. Karta tytułowa manuskryptu przedstawia tytuł pamiętnika Michała Leona Obuchowicza [transliteracja]: Krutkie Nieszczęścia mego zebranie kto / rego czasu co y kędy się dzialo A: 1660, po którym od razu rozpoczyna się część właściwa pamiętnika, znajdująca się na kartach: 3-18. Na kartach (k. 18v-32) zapisano Diariusz drogi do Moskwy w roku 1664, miesiaca Januarii 6 dnia, a dalej mowy (k. 32v-37), wśród których znalazł się kredens dla Krzysztofa Zawiszy (k. 33v-34). W dalszej części manuskryptu wpisano utwory wierszowane (k. 37v-41) i pismo publicystyczne z czasów elekcji króla Michała (k. 4lv-43).

\section{Zasady transkrypcji}

W transkrypcji korzystano z Zasad wydawania tekstów staropolskich do wydań typu B (oprac. K. Górski i in., red. M.R. Mayenowa, przykłady J. Woronczak, Wrocław 1955).

Zmodyfikowano występowanie znaków interpunkcyjnych, których pojawianie się było niezgodne z obecnie obowiązującymi zasadami. Wyjątki stanowiły zakończenia zdań, w których długość nie ingerowano.

Zachowano pisownię wielkich liter w zwrotach grzecznościowych. Autor mów poprzez ich zastosowanie pragnął okazać szacunek osobom, o których pisał, postanowiono więc nie wprowadzać zmian sprzecznych z intencją pisarza.

Zmodernizowano pisownię łączną i rozdzielną (wstan $\rightarrow$ w stan).

Uwspółcześniono pisownię ó, u, o (krutko $\rightarrow$ krótko).

Zmodernizowano pisownię i, j, y (wszechmocney $\rightarrow$ wszechmocnej, oddaiąc $\rightarrow$ oddając).

Rozszerzono ponadto grupy ij, yj, yi, (dyspozycya $\rightarrow$ dyspozycyja), w wyrazach obcego pochodzenia, gdzie y, i pełnią funkcję grup -ij, yj dodano j (komissya $\rightarrow$ komisyja)

Zastosowano transkrypcję samogłosek nosowych według reguł współczesnych (panne $\rightarrow$ pannę). Zachowano oboczność form wszystkie: wszytkie, dopiero: dopioro. 


\section{Wedding speeches from the diary of Michał Obuchowicz (critical edition)}

The Summary

The subject of the editio critica are two wedding speeches, written anonymously together with the diary of Michał Leon Obuchowicz (the manuscript from the Library of the Polish Academy of Sciences in Kórnik). The first speech is from the wedding of Prudencja Gosiewska and the second one is the exemplary speech made while giving the bride to the groom. There is a hypothesis that Michał Leon Obuchowicz is actually the author of both speeches. Even though the diaries were edited twice (in 1859, Vilnus and 2003, Warsaw), the texts have never been published. The author of the article postulates for including the editio critica in the editions of old diaries.

słowa kluczowe: oratorstwo, Michał Obuchowicz, mowa weselna, edycja krytyczna keywords: oratory, Michał Obuchowicz, wedding oration, critical edition 